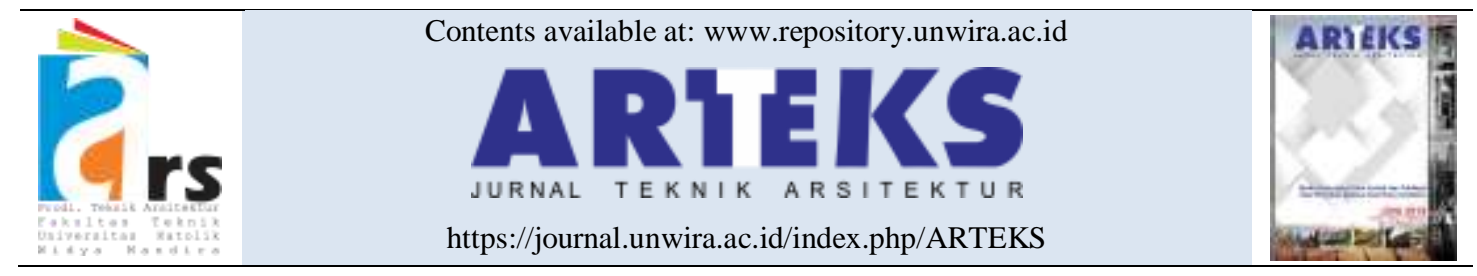

Research paper

doi: $10.30822 /$ arteks.v6i3.1103

\title{
Optimization of BIPV based on electrical energy generated and return of investment
}

\author{
Susan $^{1 *(\mathbb{D})}$, Dyah Kusuma Wardhani ${ }^{2}$, Yusuf Ariyanto $^{3(\mathbb{D}}$, Eric Harianto ${ }^{4}$ \\ 1,2, 3 Architecutre Study Program, Faculty of Creative Industries, \\ ${ }^{4}$ Management Studies Program, Faculty of Management and Business, \\ Universitas Ciputra Surabaya \\ Citraland CBD Boulevard, Surabaya, Indonesia

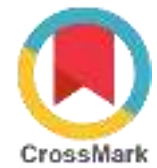

\begin{tabular}{|c|c|}
\hline ARTICLE INFO & ABSTRACT \\
\hline Article history: & \multirow{16}{*}{$\begin{array}{l}\text { The non-renewable resources used in generating electrical energy } \\
\text { have decreased. The National Energy Council reported that } \\
\text { Indonesia has huge potential renewable energy resources with the } \\
\text { highest from solar energy but only } 5 \% \text { is utilized. This is indicated } \\
\text { by the very small number of building owners willing to install the } \\
\text { technology related to renewable energy in the country due to the } \\
\text { high initial cost of installation. Moreover, existing buildings have } \\
\text { other boundaries such as the limitation caused by the structure and } \\
\text { potentially available integrated area. This study, therefore, } \\
\text { proposed a BIPV model in an existing building to contribute to the } \\
\text { maximum use of renewable energy in a relatively limited potential- } \\
\text { available integrated area. This involved the application of the } \\
\text { experimental method to several models using the amount of } \\
\text { electrical energy generated and ROI as the optimization parameters. } \\
\text { The ROI was used to provide a more comprehensive review showing } \\
\text { the period as the most critical determinant of investment to a } \\
\text { building owner. The results showed the installation of PV on an } \\
\text { opaque wall in the west orientation is the optimum configuration } \\
\text { based on its ability to generate } 77774 \text { kWh/year of electrical energy } \\
\text { which exceeds the existing consumption volume. Meanwhile, the } \\
\text { ROI was } 4.36 \text { years and this is relatively short compared to the } 25 \\
\text { years of PV life guaranteed. It is important to note that the } \\
\text { optimization of this model was supported by the largest number of } \\
\text { integrated areas and the high annual radiation it received. This } \\
\text { significant contribution of this study is that the electrical energy and } \\
\text { ROI should be fully considered by building owners in applying PV. }\end{array}$} \\
\hline Received April 28, 2021 & \\
\hline Received in revised form June 07, 2021 & \\
\hline Accepted July 06, 2021 & \\
\hline Available online December 01, 2021 & \\
\hline Keywords: & \\
\hline BIPV & \\
\hline Electrical energy & \\
\hline Existing building & \\
\hline Renewable & \\
\hline ROI & \\
\hline *Corresponding author: Susan & \\
\hline Architecutre Study Program, Faculty of & \\
\hline Surabaya, Indonesia & \\
\hline Email: susan@ciputra.ac.id & \\
\hline $\begin{array}{l}\text { ORCID: https://orcid.org/0000-0002-0924- } \\
8200\end{array}$ & \\
\hline
\end{tabular}

\section{Introduction}

There is abundant solar energy to be used as a renewable energy resource but its use in Indonesia is still very small. This is indicated by a lesser number of building owners willing to install the technology on existing buildings due to the limitation of structure and potential-available limited area as well as the high initial cost of installation. Several BIPV models have, however, been designed under different positions, tilts, and orientations and later simulated using Archipak software and mathematical models to evaluate the solar radiation received, electrical energy generated, cost of investment, and the annual cash inflow. This present study was, therefore, conducted to analyze the performance of BIPV and determine the optimum configuration in terms of electrical energy generated and ROI value. It 
also aimed to illustrate the results graphically to serve as a reference for building owners.

The Energy X.O concept (Karnama 2019) introduced four pillars covering renewable energy investments, sustainable transportation, local energy system, and new energy solutions. The concept is targeting three groups consisting of utilities, large energy consumers, and new players. This means renewable energy investment is expected to provide benefits such as asset ownership and more control, energy cost reduction, and reduction of dependency on utilities to Ciputra Group which is one of the large energy consumers. Therefore, the Universitas Ciputra building was used in this study to determine the reliability of renewable energy investment based on electrical energy production and return on investment value. The building topography is presented in figure 1 and is observed to be located in Surabaya, East Java province, Indonesia. It is geographically located on $07^{\circ} 29 \mathrm{~S}$ Latitude and $112^{\circ} 63^{\prime}$ E Longitude and this indicates the presence of abundant solar radiation. Moreover, the data obtained from local Meteorological and Geophysical Agencies showed the average solar radiation in each month for 5 years (2015-2020) in Surabaya ranged from 5632 - $7404 \mathrm{kWh} / \mathrm{m}^{2}$. The abundant solar radiation in the building is associated with its location in a suburban area with low density, not so many neighbors, and no tall buildings around. Furthermore, the building is owned by the Ciputra Group which is a pioneer in sustainable largescale development in Indonesia. It was designed based on significant efforts to reduce the need for electrical energy. This is indicated by the shallow layout, facing elongated side to north and south orientation, a vertical greenery system usage, application of a secondary skin on its east and west façade, OTTV calculation, use an inverter AC system, maximizes daylight utilization, and uses $100 \%$ electronic ballast for an artificial lighting system. These strategies subsequently reduce the thermal transfer value and cooling load needed by the building. However, this energy consumption reduction has not been complemented with efforts to supply energy from renewable resources.

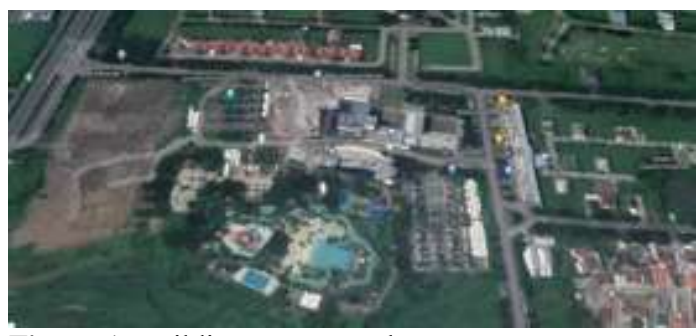

Figure 1. Building's topography

This study, therefore, proposed a BIPV model in an existing building (Universitas Ciputra) as a contribution to the maximum use of renewable energy in a relatively limited potential-available integrated area. The model was optimized based on annual electricity production as well as the return of investment. The findings showed the building owner there is a need to consider electrical energy production and return of investment in making the decision to apply PV.

Buildings are conventionally associated with huge energy consumption due to HVAC, lighting, and, recently, information and communication technologies (Vinuesa et al. 2020, 1-10). This perspective has been supported by much data. For example, building energy performance analysis in Europe showed $40 \%$ of their national energy is being consumed (Visa et al. 2014, 72-78). It has also been discovered that buildings consume onethird of the world's energy (Srinivasan et al. 2012, $300-315$ ). They are also responsible for up to $36 \%$ of GHG emissions. A similar trend was also found in Indonesia where energy consumption increases mostly from the industrial, residential, and commercial sectors (Handayani and Ariyanti 2012, 33-38). The total energy demand is 60\%$70 \%$ electrical energy sourced mostly from fossil fuel which is a non-renewable energy resource. Several strategies have been proposed to reduce the huge energy consumption. These include the use of energy-saving equipment as applied by China on its lighting system for rail transportation (Lai, Dai, and Rameezdeen 2020), increment in energy efficiency by converting waste energy into recovered energy (Karnama, Haghighi, and Vinuesa 2019, 1-3), and switching to renewable energy resources as applied in Nigeria residential housing through solar energy - solar photovoltaic or PV cells (Elinwa, Ogbeba, and Agboola 2021, $1-8)$.

Renewable sources such as wind, solar, etc. have been shown considerable attention in power production to overcome the problems of pollution and environmental degradation (El khchine and 
Sriti 2021). Indonesian Government has also consistently supported the use of renewable energy sources specifically through the issuance of a regulatory policy, the National Energy Policy, based on PP No. 79/2014 used to set up the target for Mix Energy Program to be 23\% in 2025 and $31 \%$ in 2030 (Menteri Energi dan Sumber Daya Mineral Republik Indonesia 2016). This was necessary due to the fact that only $5 \%$ of the approximately $450 \mathrm{GW}$ renewable energy resources available in the country are utilized (Departemen Rating Development Green Building Council Indonesia 2012). These contradictive numbers showed Indonesia actually has huge potential resources but their use is still very minimal due to the high initial cost of the technology needed. This, therefore, subsequently increases the cost of energy when compared to those produced using a non-renewable resource. Meanwhile, the most abundant renewable energy source in Indonesia is solar energy (Dewan Energi Nasional Republik Indonesia 2019). According to the Secretariat General of the National Energy Council, solar energy covers more than $200 \mathrm{GW}$ of the $450 \mathrm{GW}$ renewable energy sources available in the country. Most of Indonesia has approximately $4 \mathrm{kWh} / \mathrm{m}^{2}$ solar radiation intensity and this was estimated more precisely to be 4.5 $\mathrm{kWh} / \mathrm{m}^{2} /$ day in the West Region and 5.1 $\mathrm{kWh} / \mathrm{m}^{2} /$ day in the Eastern Region (Handayani and Ariyanti 2012, 33-38).

Photovoltaic is one of the most potential solar energy technologies used in generating electrical energy from a clean source (Sreenath et al. 2020, $1-5)$. One of its applications is in the BIPV which is a system used in combining PV with typical building fabrics (Elinwa, Ogbeba, and Agboola 2021). BIPV provides additional value due to its ability to generate electrical energy right in the place it is needed as well as to reduce the cost for the building's conventional façade material (Tabakovic et al. 2017). Its performance, however, depends on some group factors including those related to PV such as PV types (Kaur and Kaur 2019), numbers of cells (Salmi et al. 2012), and PV's efficiency (Bonifacius 2018). It also some building-related factors such as shading condition (Urbanetz, Zomer, and Rüther 2011), availability of integrated surface (Susan and Wardhani 2020b), and tilt and orientation angle (Hussein, Ahmad, and El-Ghetany 2004; Mehleri et al. 2010; Susan 2017; Urbanetz, Zomer, and Rüther 2011). This also an external factor in the form of solar radiation (Hussein,
Ahmad, and El-Ghetany 2004). Furthermore, there are three types of PV commonly found in the market and the most efficient is the monocrystalline but its use has certain boundaries such as its limitation to wall cladding due to its weight and opaque character. Meanwhile, glass cladding leverages the lightness and transparency of the polycrystalline and amorphous types. It is also important to note that the number of PV cells varies from 36-216 cells and the smaller modules are preferable in the installation process. Nowadays, the efficiency of PV ranges from 18\% to $19.6 \%$. Meanwhile, the shading condition which is a building-related factor is divided into two types and these include the soft and hard, thereby, causing a 25\%-30\% power reduction of electrical energy generated by BIPV. Another factor related to the building is the availability of an integrated surface, especially existing ones. It is also overlapped by the boundary of the building structure not constructed to support the PV load. This study, therefore, focused only on the impact of tilt and orientation angle on the electrical energy generated by the BIPV. As a general rule of thumb for PV installation, tilt is determined as the same angle with geographical latitude, $20^{\circ}-$ $30^{\circ}$ for areas at low latitude, or facing the equator in the orientation angle between $-15^{\circ}-15^{\circ}$ measured from the horizontal plane (Hussein, Ahmad, and El-Ghetany 2004). A previous study conducted using thin-film BIPV showed the performance of BIPV inclined at $15^{\circ}$ and placed at the east orientation was better compared to the other orientations and angles (Kumar, Sudhakar, and Samykano 2018). Another research in tropical weather conditions showed the PV installed on a façade oriented in the north direction performed lower when compared to other facades and roofs (Kumar, Sudhakar, and Samykano 2020). It is, however, generally known that solar radiation is abundant in an area near the equator and lower for those at a higher latitude. Moreover, the literature reviewed led to the formulation of the following mathematical model to calculate annual electricity:

$$
\begin{aligned}
& \text { Annual Electricity Production } \\
& =\text { efficiency x Annual Radiation Received } \mathrm{x} \\
& \text { shading coefficient } \\
& =\text { efficiency x (GxA) x shading coefficient } \\
& \text { Where, } \quad=\text { solar radiation intensity } \\
& \begin{array}{ll}
\text { G } \quad=\text { PV area } \\
\text { A } \quad=25-30 \%
\end{array}
\end{aligned}
$$


Solar radiation which is an external factor also influences the performance of BIPV in terms of its optimum temperature. The optimum performance of $\mathrm{PV}$ is at $25^{\circ} \mathrm{C}$. In fact, $\mathrm{PV}$ cells receive solar radiation during their operation and this causes the temperature to rise. A specially designed and fabricated building-integrated semitransparent PV phase change material was applied to regulate the cell temperature and the experiment produced a lower peak temperature up to $12^{\circ} \mathrm{C}$ reduction (Karthick et al. 2020). Moreover, it has also been discovered that an increase in temperature has the ability to reduce PV's performance with a discrepancy number of approximately 6\% (Trinuruk, Sorapipatana, and Chenvidhya 2009). Therefore, the net annual electricity production was calculated using:

Net Annual Electricity Production

$=$ Annual Electricity Production $\mathrm{x}$ discrepancy factor

\section{Where,}

Discrepancy factor $\quad=6 \%$

Building owners can choose either to install solar energy technology on/in a building or just purchase the electrical energy produced through a solar energy source (Marszal et al. 2012). The installation of solar technology (PV) on a building is called BAPV while the installation in a building is known as BIPV. A comparison of the two showed BIPV has advantages in terms of durability, resistance to winds, aesthetics (Kumar, Sudhakar, and Samykano 2019), reduced cost of building construction, and increased market acceptance of the buildings (Shukla et al. 2017). However, both options are mostly related to the cost of the PV and despite the reduction in the manufacturing cost, those added to a building's overall budget are quite significant. This means the building owner and other stakeholders need to learn how to determine the advantages of the PV installation from the return of investment (ROI) perspective (Carbajales-Dale et al. 2015; Hsu 2012; Dong, $\mathrm{Xu}$, and $\mathrm{Lin}$ 2017). It focuses on understanding the time or period required to recoup the expenses of the investment. This shows the significant importance of time in investment due to the fact that a longer compensation period is not regularly attractive to a building owner. ROI can be measured by dividing the cost of investment with the annual cash inflow. Meanwhile, this cost of investment depends mostly on the PV price which ranges from USD 50 to USD 100 for a $200 \mathrm{Wp}$ monocrystalline and $40 \mathrm{Wp}$ amorphous silicon module in the market. Another important cost is the cost of the installation which was found to be quite high a while ago by being approximately the same as the price needed to buy the PV module. It has, however, reduced to $50 \%$ of the module prices (Oko et al. 2012). Moreover, the annual cash inflow means savings per year received from conventional electrical cost reduction. In other words, it is the numbers of electrical energy generated by PV. This value is, therefore, usually compared with PV lifetime duration with several manufacturing companies observed to be guaranteeing approximately 25 years.

The present study aimed to analyze the performance of BIPV to determine the optimum configuration in terms of electrical energy generated and ROI value. The results are further illustrated graphically to serve as a reference for building owners. The process involved designed several BIPV models under different positions, tilts, and orientations after which they were simulated using Archipak software and mathematical models to evaluate the solar radiation received, electrical energy generated, cost of investment, and annual cash inflow.

\section{Method}

The site selected for this study supports the use of PV solar technology as previously stated and this is associated with its location in a tropical climate, sub-urban area, and also has a very minimum obstruction from its surroundings. Moreover, several significant efforts are integrated into the building design to reduce the need for electrical energy. Therefore, the research was initiated started with the observation of the existing building, the market, and the literature study. The observation of the existing building was used to collect data on electrical consumption, capital cost, and the availability of BIPV in the area. Meanwhile, market research was used for the data collection on PV cells, modules, and prices while the literature study covers the area of the group factors influencing the BIPV performance such as external, PV, and building factors. These were followed by the design of the BIPV models used in simulating the annual solar radiation based on 
the tilt and orientation angles. Furthermore, the optimization parameters were analyzed to determine the optimum BIPV model to be recommended for a building owner. The site selection and research steps are, however, presented in figure 2 .

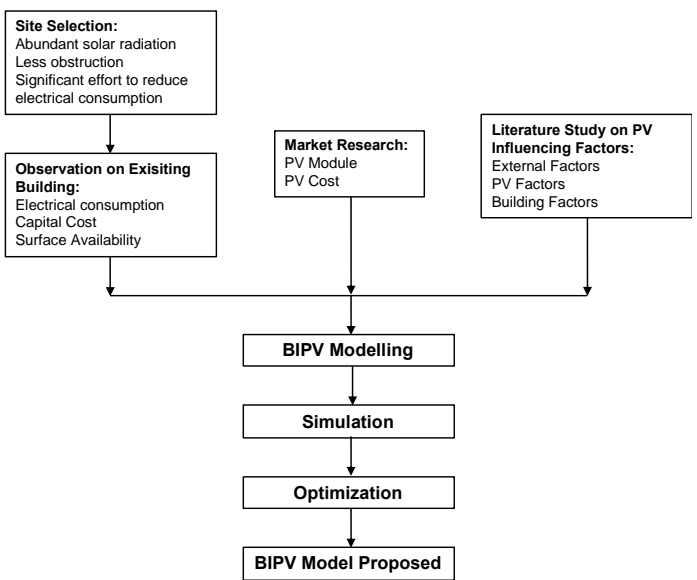

Figure 2. Site selection and research steps

The main source of electrical energy in the UC Building is from the State Electricity Company which comes from non-renewable sources. The mapping of the current energy status showed the average electrical energy consumption is between $137703.33-177845 \mathrm{kWh} /$ month while the capital cost is estimated at USD 11.333/month. Moreover, the integrated areas available were mapped to plan the PV integration on the UC Building and these include the roof, transparent wall, opaque wall, and shading device as indicated in figure 3 and table 1.

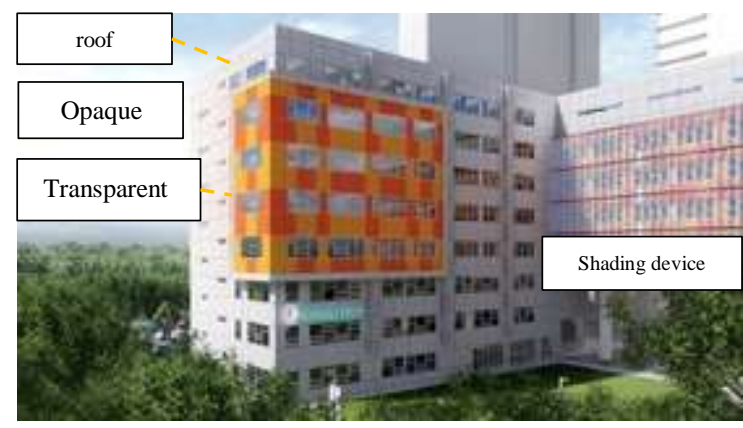

Figure 3. PV placement alternatives in UC building

Table 1. Potential area for PV integration

\begin{tabular}{lllll}
\hline $\begin{array}{l}\text { Orient } \\
\text { ation }\end{array}$ & $\begin{array}{l}\text { Transpa } \\
\text { rent wall } \\
\left(\mathbf{m}^{2}\right)\end{array}$ & $\begin{array}{l}\text { Opaque } \\
\text { wall }\left(\mathbf{m}^{\mathbf{2}}\right)\end{array}$ & $\begin{array}{l}\text { Shading } \\
\text { device } \\
\left(\mathbf{m}^{2}\right)\end{array}$ & $\begin{array}{l}\mathbf{R o o f} \\
\left(\mathbf{m}^{2}\right)\end{array}$ \\
\hline $0^{\circ}$ & 941 & 1887 & 0 & 51 \\
\hline $90^{\circ}$ & 525 & 2209 & 0 & \\
\hline $135^{\circ}$ & 0 & 0 & 1095 & \\
\hline $180^{\circ}$ & 544 & 2910 & 0 & \\
\hline $225^{\circ}$ & 0 & 0 & 879 & \\
\hline $270^{\circ}$ & 1176 & 2872 & 0 & \\
\hline
\end{tabular}

Treatments in the form of PV integration to the façade elements were applied in this experimental research using $30^{\circ}$ facing north orientation (equator) as the tilt and orientation angle for the proposed BIPV on the roof. Meanwhile, the models proposed for the opaque walls, transparent walls, and shading devices also followed the orientation of the façade elements due to the limitation of the existing conditions. Moreover, the types of PV used were selected based on high-efficiency number, handy dimension, opaqueness, and transparency and the specifications proposed to be used in each area are shown in table 2.

Table 2. PV specification

\begin{tabular}{lllllll}
\hline $\begin{array}{l}\text { Pro-posed } \\
\text { integrated area }\end{array}$ & PV type & $\begin{array}{l}\text { Number of } \\
\text { cells }\end{array}$ & $\begin{array}{l}\text { Efficiency } \\
(\boldsymbol{\%})\end{array}$ & $\begin{array}{l}\text { Peak } \\
\text { power } \\
(\mathbf{W p})\end{array}$ & $\begin{array}{l}\text { Dimension } \\
(\mathbf{m m})\end{array}$ & $\begin{array}{l}\text { Price range } \\
\text { (USD) }\end{array}$ \\
\hline Transparent wall & Amorphous & 15 & $19.0 \%$ & 80 & $1000 \times 720 \times 35$ & $48-85$ \\
\hline Opaque wall & Mono-crystalline & 72 & $18.6 \%$ & 235 & $1580 \times 798 \times 35$ & $57-100$ \\
\hline Shading device & Amorphous & 15 & $19.0 \%$ & 80 & $1000 \times 720 \times 35$ & $48-85$ \\
\hline Roof & Mono-crystalline & 72 & $18.6 \%$ & 235 & $1580 \times 798 \times 35$ & $57-100$ \\
\hline
\end{tabular}

The solar energy received in every tilt and orientation was calculated using Archipak 5.1 software while the simulations were run to obtain data on the annual radiation received per $\mathrm{m} 2$ for each month in a year as presented in table 3 . These numbers were later multiplied with the numbers of the proposed PV area to generate the total amount of annual radiation received.
Table 3. Amounts of annual radiation received

\begin{tabular}{llll}
\hline Area & $\begin{array}{l}\text { Tilt } \\
\left({ }^{\circ}\right)\end{array}$ & $\begin{array}{l}\text { Orientation } \\
\left({ }^{\circ}\right)\end{array}$ & $\begin{array}{l}\text { Annual } \\
\text { radiation } \\
\text { received } \\
\left(\mathbf{k W h} / \mathbf{m}^{2}\right)\end{array}$ \\
\hline (a) & $(\mathrm{b})$ & $(\mathrm{c})$ & $(\mathrm{d})$ \\
\hline Transparent & 90 & 0 & 2003 \\
wall and & 90 & 90 & 2217 \\
Opaque & 90 & 180 & 1777 \\
Wall & 90 & 270 & 2213 \\
& 90 & 135 & 2109
\end{tabular}




\begin{tabular}{llll}
\hline Area & $\begin{array}{l}\text { Tilt } \\
\left({ }^{\circ}\right)\end{array}$ & $\begin{array}{l}\text { Orientation } \\
\left({ }^{\circ}\right)\end{array}$ & $\begin{array}{l}\text { Annual } \\
\text { radiation } \\
\text { received } \\
\left(\mathbf{k W h} / \mathbf{m}^{2}\right)\end{array}$ \\
\hline $\begin{array}{l}\text { (a) } \\
\text { Shading }\end{array}$ & 90 & 225 & $(\mathrm{~d})$ \\
$\begin{array}{l}\text { Device } \\
\text { Roof }\end{array}$ & 30 & 0 & 2098 \\
\hline
\end{tabular}

The optimization of BIPV was measured using two parameters which are the electrical energy generated and the ROI value. Meanwhile, the ROI was calculated by dividing the cost of investment with the annual cash inflow. The cost of investment used in this study was calculated from the PV installation and the price paid by the user is typically based on the total power output of the solar panels in the system. Table 2 shows 2 types of PV used in this study and these include 15-cells amorphous and 72-cells mono-crystalline produced by a leading manufacturer with 25 years product guarantee and the prices ranged between USD 48 and USD 100 per module. The installation cost was, however, calculated as $50 \%$ of the PV module price.

The annual cash inflow is the savings received from reducing the conventional electrical cost per year. Meanwhile, the conventional electrical cost in Indonesia is divided based on some categories such as electricity rates for social services, households, business, industry, government office and public street lighting, electric train company, electricity provider business holder, and other particular users not covered by the previous categories. The UC Building is listed as a business category group of B-1/TR with $1300 \mathrm{VA}$ rated at USD $0.064 / \mathrm{kWh}$ as indicated in table 4 . In the past few years, conventional electricity rates were relatively stable but this study considered the inflation rate in calculating the ROI. The inflation rate was, however, recorded to be fluctuating between $1.32 \%$ and 3.49\% from March 2019 to October 2020. Therefore, the maximum value was used as the worst estimation in the ROI calculation.

Table 4. Categories of electrical use in Indonesia

\begin{tabular}{|c|c|c|c|c|c|}
\hline \multirow{2}{*}{ No } & \multirow{2}{*}{ Rate group } & \multirow{2}{*}{ Power limitation } & \multicolumn{2}{|l|}{ Regular } & \multirow{2}{*}{$\begin{array}{l}\text { Pre-paid } \\
\text { (USD) }\end{array}$} \\
\hline & & & Load cost & Consumption cost & \\
\hline 1. & B-1/TR & $450 \mathrm{VA}$ & 23.500 & $\begin{array}{l}\text { Group 1: } 0-30 \mathrm{kWh}: 254 \\
\text { Group 2: >30 kWh: } 420\end{array}$ & 0.036 \\
\hline 2. & B-1/TR & $900 \mathrm{VA}$ & 26.500 & $\begin{array}{l}\text { Group 1: } 0-30 \mathrm{kWh}: 254 \\
\text { Group 2: }>30 \mathrm{kWh}: 420\end{array}$ & 0.042 \\
\hline 3. & B-1/TR & $1300 \mathrm{VA}$ & *) & 966 & 0.064 \\
\hline 4. & $\mathrm{~B}-1 / \mathrm{TR}$ & $2200-5500$ & $*)$ & 1100 & 0.073 \\
\hline 5. & $\mathrm{~B}-2 / \mathrm{TR}$ & $6600-200 \mathrm{kVA}$ & *) & 1352 & 0.090 \\
\hline 6. & B-3/TM & $>200 \mathrm{kVA}$ & $* *)$ & $\begin{array}{l}\text { PLT }=\mathrm{K} \times 1020 \\
\text { BPLT }=1020 \\
\mathrm{kVArh}=1117\end{array}$ & - \\
\hline
\end{tabular}

The value obtained was compared with PV lifetime duration which was estimated at 25 years by several manufacturers.

\section{Result and discussion}

\section{BIPV models}

The general rule of thumb from previous research was used to design several PV models on a building facade as indicated in table 5 .

Table 5. Proposed BIPV models

\begin{tabular}{|c|c|c|c|c|c|c|c|}
\hline Area & $\begin{array}{l}\text { Numbers of } \\
\text { potential } \\
\text { integrated } \\
\text { area }\left(\mathbf{m}^{2}\right)\end{array}$ & Code & Modelling & $\begin{array}{l}\text { Tilt/ } \\
\text { orien } \\
\text { tation } \\
\left({ }^{\circ}\right) \\
\end{array}$ & $\begin{array}{l}\text { Area } \\
\text { per } \\
\text { module } \\
\left(\mathbf{m}^{2}\right) \\
\end{array}$ & $\begin{array}{l}\text { Numbers of } \\
\text { PV } \\
\text { integrated } \\
\text { area }\left(\mathbf{m}^{2}\right) \\
\end{array}$ & $\begin{array}{l}\text { Numbers } \\
\text { of PV }\end{array}$ \\
\hline (a) & (b) & & (c) & (d) & (e) & (f) & (g) \\
\hline Roof & 509.79 & $\mathrm{R}$ & & 30 & 1.13 & 509.63 & 451 \\
\hline
\end{tabular}




\begin{tabular}{|c|c|c|c|c|c|c|c|}
\hline Area & $\begin{array}{l}\text { Numbers of } \\
\text { potential } \\
\text { integrated } \\
\text { area }\left(\mathbf{m}^{2}\right)\end{array}$ & Code & Modelling & $\begin{array}{l}\text { Tilt/ } \\
\text { orien } \\
\text { tation } \\
\left({ }^{\circ}\right)\end{array}$ & $\begin{array}{l}\text { Area } \\
\text { per } \\
\text { module } \\
\left(\mathbf{m}^{2}\right) \\
\end{array}$ & $\begin{array}{l}\text { Numbers of } \\
\text { PV } \\
\text { integrated } \\
\text { area }\left(\mathbf{m}^{2}\right)\end{array}$ & $\begin{array}{l}\text { Numbers } \\
\text { of PV }\end{array}$ \\
\hline (a) & (b) & & (c) & (d) & (e) & (f) & (g) \\
\hline $\begin{array}{l}\text { Opaque wall } \\
\text { (North) }\end{array}$ & 1886.59 & OWn & & 0 & 1.26 & 1886.22 & 1497 \\
\hline $\begin{array}{l}\text { Opaque Wall } \\
\text { (East) }\end{array}$ & 2208.96 & Owe & & 90 & 1.26 & 2208.78 & 1753 \\
\hline $\begin{array}{l}\text { Opaque wall } \\
\text { (West) }\end{array}$ & 2872.30 & OWw & & 270 & 1.26 & 2871.54 & 2279 \\
\hline $\begin{array}{l}\text { Transparent } \\
\text { wall (North) }\end{array}$ & 941.21 & TWn & & 0 & 0.79 & 940.89 & 1191 \\
\hline $\begin{array}{l}\text { Transparent } \\
\text { wall (East) }\end{array}$ & 524.88 & TWe & & 90 & 0.79 & 524.56 & 664 \\
\hline $\begin{array}{l}\text { Transparent } \\
\text { wall (West) }\end{array}$ & 1175.55 & TWW & & 270 & 0.79 & 1175.52 & 1488 \\
\hline $\begin{array}{l}\text { Shading } \\
\text { device (East) }\end{array}$ & 1094.87 & $\mathrm{SDe}$ & & 135 & 1.13 & 1093.84 & 968 \\
\hline $\begin{array}{l}\text { Shading } \\
\text { Device } \\
\text { (West) }\end{array}$ & 897.22 & SDw & & 225 & 0.81 & 896.67 & 1107 \\
\hline
\end{tabular}

Annual energy generation

The electrical energy generated was calculated by multiplying the data of annual radiation received in each orientation $\left(\mathrm{kWh} / \mathrm{m}^{2}\right)$ from Archipak 5.1 as presented in table 3 with the numbers of PV integrated area. The results were adjusted based on the concerns associated with shadow condition, PV efficiency, and discrepancy factor, and the electrical energy generated is tabulated in table 6 with the highest observed to be generated by the $\mathrm{OWw}$ model as seen in figure 4.

Table 6. Electrical energy generated

\begin{tabular}{|c|c|c|c|c|c|c|c|c|}
\hline $\begin{array}{l}\text { Area } \\
\text { code }\end{array}$ & $\begin{array}{l}\text { Orienta } \\
\text { tion/tilt } \\
\left({ }^{\circ}\right)\end{array}$ & $\begin{array}{l}\text { Numbers of } \\
\text { PV integra- } \\
\text { ted area }\left(\mathrm{m}^{2}\right)\end{array}$ & $\begin{array}{l}\text { Annual } \\
\text { radiation } \\
\text { received } \\
\left(\mathrm{kWh} / \mathrm{m}^{2}\right)\end{array}$ & $\begin{array}{l}\text { Annual radiation } \\
\text { received before } \\
\text { shadow } \\
(\mathrm{kWh})\end{array}$ & $\begin{array}{l}\text { Annual } \\
\text { radiation } \\
\text { received after } \\
\text { shadow } \\
(\mathrm{kWh}) \\
\end{array}$ & $\begin{array}{l}\text { PV } \\
\text { efficiency } \\
(\%)\end{array}$ & $\begin{array}{l}\text { Annual } \\
\text { electrical } \\
\text { energy } \\
\text { generated } \\
(\mathrm{kWh}) \\
\end{array}$ & $\begin{array}{l}\text { Annual Electrica } \\
\text { energy generated } \\
\text { with discrepancy } \\
\text { factor } \\
(\mathrm{kWh})\end{array}$ \\
\hline & $\mathrm{a}$ & $\mathrm{b}$ & $\mathrm{c}$ & $\mathrm{d}=\mathrm{b} \times \mathrm{c}$ & $e=d-30 \%$ & $\mathrm{f}$ & $g=e \times f$ & $\mathrm{~h}=\mathrm{g}-6 \%$ \\
\hline $\mathrm{R}$ & 30 & 509.63 & 2082 & 1061049.66 & 742734.76 & 18.6 & 138148.67 & 129859.75 \\
\hline $\mathrm{OWn}$ & 0 & 1886.22 & 2003 & 3778098.66 & 2644669.06 & 18.6 & 491908.45 & 462393.94 \\
\hline
\end{tabular}




\begin{tabular}{|c|c|c|c|c|c|c|c|c|}
\hline $\begin{array}{l}\text { Area } \\
\text { code }\end{array}$ & $\begin{array}{l}\text { Orienta } \\
\text { tion/tilt } \\
\left({ }^{\circ}\right)\end{array}$ & $\begin{array}{l}\text { Numbers of } \\
\text { PV integra- } \\
\text { ted area }\left(\mathrm{m}^{2}\right)\end{array}$ & $\begin{array}{l}\text { Annual } \\
\text { radiation } \\
\text { received } \\
\left(\mathrm{kWh} / \mathrm{m}^{2}\right)\end{array}$ & $\begin{array}{l}\text { Annual radiation } \\
\text { received before } \\
\text { shadow } \\
(\mathrm{kWh})\end{array}$ & $\begin{array}{l}\text { Annual } \\
\text { radiation } \\
\text { received after } \\
\text { shadow } \\
(\mathrm{kWh}) \\
\end{array}$ & $\begin{array}{l}\text { PV } \\
\text { efficiency } \\
(\%)\end{array}$ & $\begin{array}{l}\text { Annual } \\
\text { electrical } \\
\text { energy } \\
\text { generated } \\
(\mathrm{kWh})\end{array}$ & $\begin{array}{l}\text { Annual Electrical } \\
\text { energy generated } \\
\text { with discrepancy } \\
\text { factor } \\
(\mathrm{kWh})\end{array}$ \\
\hline & $\mathrm{a}$ & $\mathrm{b}$ & c & $d=b \times c$ & $e=d-30 \%$ & $\mathrm{f}$ & $g=e \times f$ & $\mathrm{~h}=\mathrm{g}-6 \%$ \\
\hline OWe & 90 & 2208.78 & 2217 & 4896865.26 & 3427805.68 & 18.6 & 637571.86 & 599317.55 \\
\hline OWw & 270 & 2871.54 & 2213 & 6354718.02 & 4448302.61 & 18.6 & 827384.29 & 777741.23 \\
\hline TWn & 0 & 940.89 & 2003 & 1884602.67 & 1319221.87 & 19.0 & 250652.16 & 235613.03 \\
\hline TWe & 90 & 524.56 & 2217 & 1162949.52 & 814064.66 & 19.0 & 154672.29 & 145391.95 \\
\hline TWw & 270 & 1175.52 & 2213 & 2601425.76 & 1820998.03 & 19.0 & 345989.63 & 325230.25 \\
\hline SDe & 135 & 1093.84 & 2109 & 2306908.56 & 1614835.99 & 19.0 & 306818.84 & 288409.71 \\
\hline SDw & 225 & 896.67 & 2098 & 1881213.66 & 1316849.56 & 19.0 & 250201.42 & 235189.33 \\
\hline
\end{tabular}

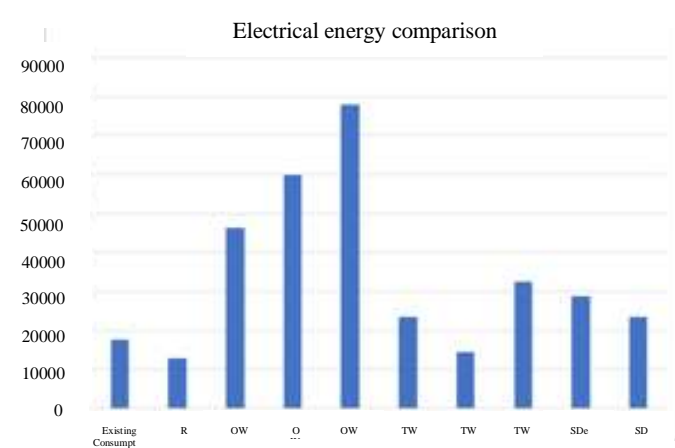

Figure 4. PV electrical energy comparison

Return on Investment (ROI)

The optimization was measured by the electrical energy generated and ROI as previously explained. The optimum price of the PV used was USD 85 for amorphous silicon and USD 100 for monocrystalline silicon and the total cost of investment for each is presented in table 7. Meanwhile, the annual cash inflow was calculated by multiplying the electrical energy generated by the PV with the USD $10.08 / \mathrm{kWh}$ buying price stated by the government for electrical energy generated from renewable energy sources, and the results are presented in table 8 . The results for ROI are, however, presented in table 9 with the shortest time, 4.25 years, found in the SDe model as seen in figure 5 .

Table 7. Cost of investment

\begin{tabular}{|c|c|c|c|c|c|}
\hline \multirow[b]{2}{*}{$\begin{array}{l}\text { Co } \\
\text { de }\end{array}$} & \multicolumn{5}{|c|}{ Cost of Investment } \\
\hline & $\begin{array}{c}\text { Num } \\
\text { bers } \\
\text { of } \\
\text { PV } \\
\text { mod } \\
\text { ule }\end{array}$ & $\begin{array}{c}\text { PV } \\
\text { price } \\
\text { /mod } \\
\text { ule } \\
\text { USD }\end{array}$ & $\begin{array}{c}\text { Total } \\
\text { PV } \\
\text { Price } \\
\\
\text { USD }\end{array}$ & $\begin{array}{c}\begin{array}{c}\text { Install } \\
\text { ation } \\
\text { Price }\end{array} \\
\text { USD }\end{array}$ & $\begin{array}{c}\begin{array}{c}\text { Total Cost } \\
\text { of } \\
\text { Investment }\end{array} \\
\text { USD }\end{array}$ \\
\hline $\mathrm{R}$ & 451 & 100 & 45100 & $\begin{array}{l}22550 . \\
0\end{array}$ & 67650.0 \\
\hline $\begin{array}{l}\mathrm{O} \\
\mathrm{W}\end{array}$ & 1497 & 100 & 149700 & $\begin{array}{l}74850 . \\
0\end{array}$ & 224550.0 \\
\hline
\end{tabular}

\begin{tabular}{lccccc}
\hline & \multicolumn{5}{c}{ Cost of Investment } \\
\cline { 2 - 6 } & $\begin{array}{c}\text { Num } \\
\text { bers } \\
\text { Co } \\
\text { de }\end{array}$ & $\begin{array}{c}\text { PV } \\
\text { price } \\
\text { PV } \\
\text { /mod } \\
\text { mod } \\
\text { ule }\end{array}$ & $\begin{array}{c}\text { Total } \\
\text { PV } \\
\text { USD }\end{array}$ & $\begin{array}{c}\text { Install } \\
\text { ation } \\
\text { Price }\end{array}$ & $\begin{array}{c}\text { Total Cost } \\
\text { of } \\
\text { Investment }\end{array}$ \\
\hline O & 1753 & 100 & 175300 & 87650. & 262950.0 \\
W & & & & 0 & \\
e & & & & & \\
U & 2279 & 100 & 227900 & 113950 & 341850.0 \\
W & & & & .0 & \\
w & & & 101235 & 50617. & 151852.5 \\
T & 1191 & 85 & & 5 & \\
W & & & & & \\
n & & & 56440 & 28220. & 84660.0 \\
T & 664 & 85 & & 0 & \\
W & & & & & \\
e & & & 126480 & 63240. & 189720.0 \\
T & 1488 & 85 & & 0 & \\
W & & & & & \\
w & & & 82280 & 41140. & 123420.0 \\
SD & 968 & 85 & & 0 & \\
e & & & & & \\
SD & 1107 & 85 & 94095 & 47047. & 141142.5 \\
w & & & & 5 & \\
\hline & & & & & \\
\hline
\end{tabular}

Table 8. Annual cash inflows

\begin{tabular}{llll} 
Code & $\begin{array}{l}\text { Electrical } \\
\text { energy } \\
\text { generated by } \\
\text { PV }\end{array}$ & $\begin{array}{l}\text { Government } \\
\text { buying price }\end{array}$ & $\begin{array}{l}\text { Annual } \\
\text { cash } \\
\text { inflows }\end{array}$ \\
\cline { 2 - 4 } (kWh) & (USD/kWh) & (USD) \\
\hline R & 129859.75 & 0.1008 & 13089.86 \\
OWn & 462393.94 & 0.1008 & 46609.31 \\
OWe & 599317.55 & 0.1008 & 60411.21 \\
OWw & 777741.23 & 0.1008 & 78396.32 \\
TWn & 235613.03 & 0.1008 & 23749.79 \\
TWe & 145391.95 & 0.1008 & 14655.51 \\
TWw & 325230.25 & 0.1008 & 32783.21 \\
SDe & 288409.71 & 0.1008 & 29071.70 \\
SDw & 235189.33 & 0.1008 & 23707.08
\end{tabular}

Table 9. ROI

\begin{tabular}{llll}
\hline Code & $\begin{array}{l}\text { Cost of } \\
\text { investment }\end{array}$ & $\begin{array}{l}\text { Annual } \\
\text { cash } \\
\text { inflows }\end{array}$ & \multirow{2}{*}{ ROI } \\
\cline { 2 - 3 } & (USD) & (USD) & \\
\hline $\mathrm{R}$ & 67650.0 & 13089.86 & 5.17 \\
OWn & 224550.0 & 46609.31 & 4.81 \\
OWe & 262950.0 & 60411.21 & 4.35
\end{tabular}




\begin{tabular}{llll}
\hline \multirow{2}{*}{ Code } & $\begin{array}{l}\text { Cost of } \\
\text { investment }\end{array}$ & $\begin{array}{l}\text { Annual } \\
\text { cash } \\
\text { inflows }\end{array}$ & ROI \\
\cline { 2 - 3 } & (USD) & (USD) & \\
\hline OWw & 341850.0 & 78396.32 & 4.36 \\
TWn & 151852.5 & 23749.79 & 6.39 \\
TWe & 84660.0 & 14655.51 & 5.78 \\
TWw & 189720.0 & 32783.21 & 5.79 \\
SDe & 123420.0 & 29071.70 & 4.25 \\
SDw & 141142.5 & 23707.08 & 5.95
\end{tabular}

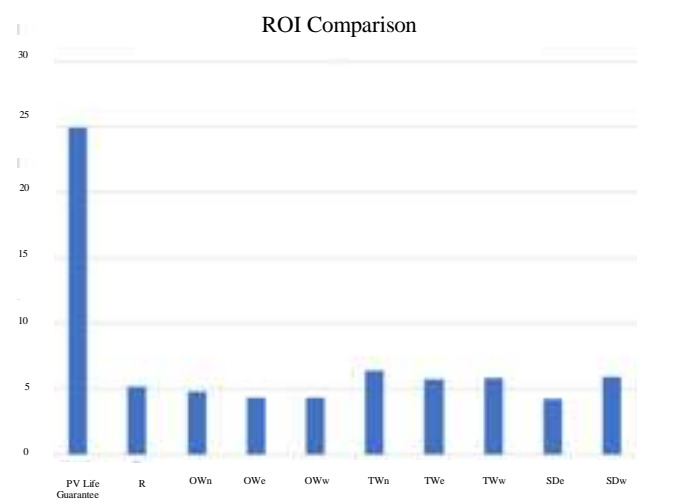

Figure 5. ROI comparison

\section{Optimization}

The optimization process was used to determine the best BIPV model for the building owner based on the highest electrical energy generated and shortest ROI. The types of configuration observed are presented in table 5 and they include the models where the PV is proposed to be integrated on a building's roof, opaque wall, transparent wall, and shading device. Two variables were used for the optimization as previously mentioned and these include electrical energy and ROI. The baseline for electrical energy is monthly electrical consumption while the baseline for the ROI is PV lifetime guarantee. Therefore, a gradient diagram was used to analyze the BIPV models as indicated in figure 6.

The electrical energy generated by BIPV was compared with the building's electrical consumption and the results showed two models including TWe and R were unable to reach the baseline while seven including TWn, TWw, SDw, $\mathrm{SDe}$, Own, OWe, and OWw met the requirement by generating electrical energy above UC electrical consumption and having ROI under the guarantee period. Time has been said to be a critical determinant of investment due to the fact that longer compensation periods are regularly not attractive to a building owner. Therefore, the ROI calculation showed all the models have relatively shorter compensation periods which ranged from 4.25 to 6.39 years when compared to the 25 years PV life guarantee

OWe, OWw, and SDe have relatively the same ROI which is $4.35,4.36$, and 4.25 years respectively. Meanwhile, OWw has the highest number of electrical energies generated followed by OWe due to its larger integrated area of $2871.54 \mathrm{~m}^{2}$ when compared to $2208.78 \mathrm{~m}^{2}$ for OWe. Moreover, the east and west orientations received almost the same annual radiation with $2217 \mathrm{kWh} / \mathrm{m}^{2}$ year and $2213 \mathrm{kWh} / \mathrm{m}^{2}$ year respectively. Therefore, $\mathrm{OWw}$ is proposed as the optimum model to be recommended for building owners.

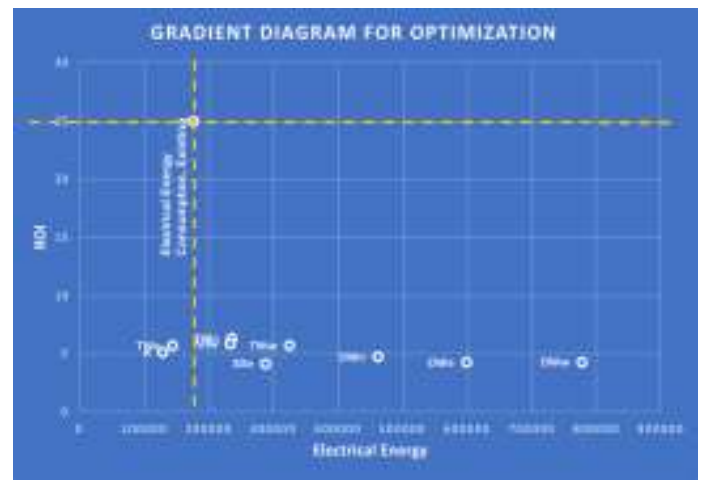

Figure 6. Gradient diagram for optimization

\section{Conclusion}

There are two main considerations when installing PV in an existing building which are the amount of electrical energy generated and the ROI. Therefore, this study started with the mapping of existing electrical consumption, capital cost, and potential-available areas in order to propose an optimum model. This was followed by the use of the general rule of thumb from a previous study to simulate several models in order to determine the optimum to be recommended for the owner of the building.

OWw was selected as the optimum model and it proposed the integration of the PV on the opaque wall, west façade, and $270^{\circ}$ orientation angle. Its selection was, therefore, based on its ability to generate $777741.23 \mathrm{kWh} / \mathrm{year}$ and an ROI value of 4.36 years. In this model, the monocrystalline silicon PV with $18.6 \%$ efficiency was simulated to be installed in the west opaque wall. Moreover, its high electrical energy generation 
was associated with its large number of integrated areas and relatively higher annual radiation received. This is in line with some previous studies conducted on factors affecting BIPV performance such as those related to the potentialavailable integrated area (Susan and Wardhani 2020a), and orientation and solar intensity (Hussein, Ahmad, and El-Ghetany 2004; Mehleri et al. 2010; Urbanetz, Zomer, and Rüther 2011).

The findings are also in line with the previous research on how BIPV can be the most potential and feasible renewable technology to be applied. This is indicated the ability of the electrical energy generated to fulfill the building's need as well as the relatively short ROI of the installation. Future studies are, however, recommended to cover other economic performance parameters such as BEP and LCOE. It is, however, important to note that the use of BIPV in an existing building has structure limitations. Therefore, it is suggested that it is planned from the design phase to ensure perfect integration both aesthetically and functionally.

\section{References}

Bonifacius, Nurhamdoko. 2018. 'Komparasi Biaya Rutin Antara BIPV, Genset Dan PLN Daya Setara 900VA'. Mintakat: Jurnal Arsitektur 19 https://doi.org/10.26905/mj.v19i2.3222.

Carbajales-Dale, Michael, Marco Raugei, Vasilis Fthenakis, and Charles Barnhart. 2015. 'Energy Return on Investment (EROI) of Solar PV: An Attempt at Reconciliation [Point of View]'. Proceedings of the IEEE 103 (7): 995-99. https://doi.org/10.1109/JPROC.2015.243847 1.

Departemen Rating Development Green Building Council Indonesia. 2012. 'GREENSHIP Untuk Gedung BaruVersi 1.1'. Jakarta. https://docplayer.info/46294107-Greenshipuntuk-gedung-baru-versi-1-1-greenship-newbuilding.html.

Dewan Energi Nasional Republik Indonesia. 2019. 'Indonesia Energy Outlook 2019'. Jakarta

Selatan. https://www.den.go.id/index.php/publikasi/in dex/EnergyOutlook.

Dong, Rentao, Jiuping $\mathrm{Xu}$, and Bo Lin. 2017. 'ROI-Based Study on Impact Factors of
Distributed PV Projects by LSSVM-PSO'. Energy $124 \quad$ (April): $336-49$. https://doi.org/10.1016/j.energy.2017.02.056.

Elinwa, Ugochukwu K., John Emmanuel Ogbeba, and O. Philips Agboola. 2021. 'Cleaner Energy in Nigeria Residential Housing'. Results in Engineering 9 (March): 100103. https://doi.org/10.1016/j.rineng.2020.100103.

Handayani, Noer Abyor, and Dessy Ariyanti. 2012. 'Potency of Solar Energy Applications in Indonesia'. International Journal of Renewable Energy Development 1 (2): 33-38. https://doi.org/10.14710/ijred.1.2.33-38.

Hsu, Chiung-Wen. 2012. 'Using a System Dynamics Model to Assess the Effects of Capital Subsidies and Feed-in Tariffs on Solar PV Installations'. Applied Energy 100 (December): 205-17. https://doi.org/10.1016/j.apenergy.2012.02.0 39.

Hussein, H.M.S., G.E. Ahmad, and H.H. ElGhetany. 2004. 'Performance Evaluation of Photovoltaic Modules at Different Tilt Angles and Orientations'. Energy Conversion and Management 45 (15-16): 2441-52. https://doi.org/10.1016/j.enconman.2003.11.0 13.

Karnama, Ahmad. 2019. 'ENERGY X.0: Future of Energy Systems'. Results in Engineering 3 (September):

100029. https://doi.org/10.1016/j.rineng.2019.100029.

Karnama, Ahmad, Ehsan Bitaraf Haghighi, and Ricardo Vinuesa. 2019. 'Organic Data Centers: A Sustainable Solution for Computing Facilities'. Results in Engineering $4 \quad$ (December): 100063. https://doi.org/10.1016/j.rineng.2019.100063.

Karthick, A., K. Kalidasa Murugavel, Aritra Ghosh, K. Sudhakar, and P. Ramanan. 2020. 'Investigation of a Binary Eutectic Mixture of Phase Change Material for Building Integrated Photovoltaic (BIPV) System'. Solar Energy Materials and Solar Cells 207 (April):

110360. https://doi.org/10.1016/j.solmat.2019.110360

Kaur, Harpreet, and Inderpreet Kaur. 2019. 'Energy Return on Investment Analysis of a Solar Photovoltaic System'. In Innovation in Energy Systems - New Technologies for Changing Paradigms. IntechOpen. https://doi.org/10.5772/intechopen.86349.

khchine, Younes El, and Mohammed Sriti. 2021. 'Performance Evaluation of Wind Turbines 
for Energy Production in Morocco's Coastal Regions'. Results in Engineering 10 (June): 100215. https://doi.org/10.1016/j.rineng.2021.100215.

Kumar, Nallapaneni Manoj, K. Sudhakar, and M. Samykano. 2018. 'Performance of Thin-Film BIPV as Double Sloped Pitched Roof in Buildings of Malaysia'. Energy Sources, Part A: Recovery, Utilization, and Environmental Effects $\quad 40 \quad$ (20): $2476-84$. https://doi.org/10.1080/15567036.2018.1502 847.

. 2019. 'Performance Comparison of BAPV and BIPV Systems with C-Si, CIS and CdTe Photovoltaic Technologies under Tropical Weather Conditions'. Case Studies in Thermal Engineering 13 (March): 100374. https://doi.org/10.1016/j.csite.2018.100374.

- 2020. 'Performance Evaluation of CdTe BIPV Roof and Façades in Tropical Weather Conditions'. Energy Sources, Part A: Recovery, Utilization, and Environmental Effects $\quad 42 \quad$ (9): $1057-71$. https://doi.org/10.1080/15567036.2019.1602 216.

Lai, XiaoDong, MengYun Dai, and Raufdeen Rameezdeen. 2020. 'Energy Saving Based Lighting System Optimization and Smart Control Solutions for Rail Transportation: Evidence from China'. Results in Engineering $5 \quad$ (March): 1-12. https://doi.org/10.1016/j.rineng.2020.100096.

Marszal, Anna Joanna, Per Heiselberg, Rasmus Lund Jensen, and Jesper Nørgaard. 2012. 'OnSite or off-Site Renewable Energy Supply Options? Life Cycle Cost Analysis of a Net Zero Energy Building in Denmark'. Renewable Energy 44 (August): 154-65. https://doi.org/10.1016/j.renene.2012.01.079.

Mehleri, E.D., P.L. Zervas, H. Sarimveis, J.A. Palyvos, and N.C. Markatos. 2010. 'Determination of the Optimal Tilt Angle and Orientation for Solar Photovoltaic Arrays'. Renewable Energy 35 (11): 2468-75. https://doi.org/10.1016/j.renene.2010.03.006.

Menteri Energi dan Sumber Daya Mineral Republik Indonesia. 2016. Peraturan Menteri Energi Dan Sumber Daya Mineral Tentang Tarif Tenaga Listrik Yang Disediakan Oleh PT Perusahaan Listrik Negara (Persero). Indonesia: BN 2016/ NO 1566; PERATURAN.GO.ID : 8 HLM.
https://peraturan.bpk.go.id/Home/Details/141 254/permen-esdm-no-28-tahun-2016.

Oko, COC, E.O Diemuodeke, E.O Omunakwe, and E Nnamdi. 2012. 'Design and Economic Analysis of a Photovoltaic System: A Case Study'. International Journal of Renewable Energy Development 1 (3): 65. https://doi.org/10.14710/ijred.1.3.65-73.

Salmi, Tarak, Mounir Bouzguenda, Adel Gastli, and Ahmed Masmoudi. 2012. 'MATLABSimulink Based Modelling of Solar .Pdf'. International Journal of Renewable Energy Research-IJRER 2 (2). https://www.ijrer.org/ijrer/index.php/ijrer/arti cle/view/157/pdf.

Shukla, Akash Kumar, K. Sudhakar, Prashant Baredar, and R. Mamat. 2017. 'BIPV in Southeast Asian Countries - Opportunities and Challenges'. Renewable Energy Focus 21 (October): 25-32. https://doi.org/10.1016/j.ref.2017.07.001.

Sreenath, S., K. Sudhakar, A.F. Yusop, Erdem Cuce, and Evgeny Solomin. 2020. 'Analysis of Solar PV Glare in Airport Environment: Potential Solutions'. Results in Engineering 5 (March). https://doi.org/10.1016/j.rineng.2019.100079.

Srinivasan, Ravi S., William W. Braham, Daniel E. Campbell, and Charlie D. Curcija. 2012. 'Re(De)Fining Net Zero Energy: Renewable Emergy Balance in Environmental Building Design'. Building and Environment 47 (January): 300-315. https://doi.org/10.1016/j.buildenv.2011.07.01 0 .

Susan, Susan. 2017. 'Integrated Configuration of Folding Wall-BIPV at Office Building in Surabaya as Low Carbon Building Design'. Humaniora $\quad 8 \quad 31$. https://doi.org/10.21512/humaniora.v8i1.369 4.

Susan, Susan, and Dyah Wardhani. 2020a. 'Building Integrated Photovoltaic as GREENSHIP'S on Site Renewable Energy Tool'. Results in Engineering 7 (September): 100153.

https://doi.org/10.1016/j.rineng.2020.100153.

Susan, Susan, and Dyah Kusuma Wardhani. 2020b. 'Photovoltaic and Wind Turbine: A Comparison as Building Integrated Renewable Energy in Indonesia'. Humaniora $11 \quad(1)$ : 51. 
https://doi.org/10.21512/humaniora.v11i1.62 94.

Tabakovic, Momir, Hubert Fechner, Wilfried van Sark, Atse Louwen, George Georghiou, George Makrides, Eliza Loucaidou, et al. 2017. 'Status and Outlook for Building Integrated Photovoltaics (BIPV) in Relation to Educational Needs in the BIPV Sector'. Energy Procedia 111 (March): 993-99. https://doi.org/10.1016/j.egypro.2017.03.262.

Trinuruk, Piyatida, Chumnong Sorapipatana, and Dhirayut Chenvidhya. 2009. 'Estimating Operating Cell Temperature of BIPV Modules in Thailand'. Renewable Energy 34 (11): 2515-23. https://doi.org/10.1016/j.renene.2009.02.027.

Urbanetz, Jair, Clarissa Debiazi Zomer, and Ricardo Rüther. 2011. 'Compromises between Form and Function in Grid-Connected, Building-Integrated Photovoltaics (BIPV) at Low-Latitude Sites'. Building and Environment $46 \quad$ (10): 2107-13. https://doi.org/10.1016/j.buildenv.2011.04.02 4.

Vinuesa, Ricardo, Hossein Azizpour, Iolanda Leite, Madeline Balaam, Virginia Dignum, Sami Domisch, Anna Felländer, Simone Daniela Langhans, Max Tegmark, and
Francesco Fuso Nerini. 2020. 'The Role of Artificial Intelligence in Achieving the Sustainable Development Goals'. Nature Communications $11 \quad$ (1): 233. https://doi.org/10.1038/s41467-019-14108-y.

Visa, Ion, Macedon D. Moldovan, Mihai Comsit, and Anca Duta. 2014. 'Improving the Renewable Energy Mix in a Building toward the Nearly Zero Energy Status'. Energy and Buildings 68 (January): $72-78$. https://doi.org/10.1016/j.enbuild.2013.09.023

\section{Author(s) contribution}

Susan contributed to the research concepts preparation, methodologies, investigations, data analysis, visualization, articles drafting and revisions.

Dyah Kusuma Wardhani contribute to the research concepts preparation and literature reviews, data analysis, of article drafts preparation and validation.

Yusuf Ariyanto contribute to methodology, supervision, and validation.

Eric Harianto contribute to methodology, supervision, and validation. 